\title{
Robert Reynolds Macintosh, M.D. (1897-1989): Forefather of Anesthesiology, Advocate for Patient Safety.
}

\author{
Haig Minassian \\ Thomas Jefferson University \\ Scott W. Cowan \\ Thomas Jefferson University \\ Charles J. Yeo \\ Thomas Jefferson University
}

Follow this and additional works at: https://jdc.jefferson.edu/gibbonsocietyprofiles

Part of the Anesthesiology Commons, and the History of Science, Technology, and Medicine Commons

\section{Let us know how access to this document benefits you}

\section{Recommended Citation}

Minassian, Haig; Cowan, Scott W.; and Yeo, Charles J., "Robert Reynolds Macintosh, M.D. (1897-1989): Forefather of Anesthesiology, Advocate for Patient Safety." (2017). Department of Surgery Gibbon Society Historical Profiles. Paper 49.

https://jdc.jefferson.edu/gibbonsocietyprofiles/49

This Article is brought to you for free and open access by the Jefferson Digital Commons. The Jefferson Digital Commons is a service of Thomas Jefferson University's Center for Teaching and Learning (CTL). The Commons is a showcase for Jefferson books and journals, peer-reviewed scholarly publications, unique historical collections from the University archives, and teaching tools. The Jefferson Digital Commons allows researchers and interested readers anywhere in the world to learn about and keep up to date with Jefferson scholarship. This article has been accepted for inclusion in Department of Surgery Gibbon Society Historical Profiles by an authorized administrator of the Jefferson Digital Commons. For more information, please contact: JeffersonDigitalCommons@jefferson.edu. 


\section{Brief Reports}

Brief Reports should be submitted online to www.editorialmanager.com/ amsurg. (See details online under "Instructions for Authors".) They should be no more than 4 double-spaced pages with no Abstract or sub-headings, with a maximum of four (4) references. If figures are included, they should be limited to two (2). The cost of printing color figures is the responsibility of the author.

In general, authors of case reports should use the Brief Report format.

\section{Robert Reynolds Macintosh, M.D. (1897-1989): Forefather of Anesthesiology, Advocate for Patient Safety}

Dr. Robert Reynolds Macintosh's contributions as a physician were essential to the growth of surgery and anesthesiology in the past several decades. However, his eclectic and fascinating life story-not as widely recognized-was in many ways just as compelling. In honor of a man aloof to the spotlight, undaunted by personal or professional challenges, and selflessly in pursuit of safer medical standards, a biographical sketch is presented.

The eponymous "Macintosh blade" facilitates laryngoscopy for the purpose of tracheal intubation. Through its elegant yet simple design, it provides a safe, efficacious approach to airway management that has been essential to the advancement of modern medicine. This apparatus, conceived in a period of incipient anesthetic sophistication, emanated from the mind of a visionary creator. Fueled by his commendable predilections for patient safety and practical problem-solving, Robert Reynolds Macintosh forever imbued the fields of anesthesiology and surgery with the spirit of his illustrious life and career.

Robert Reynolds Macintosh was born Rewi Rawhiti Macintosh in Timaru, New Zealand, in 1897.1,2 He spent the earlier part of his childhood in Argentina, and returned to New Zealand at age 13 to attend the prestigious Waitaki Boys' High School in Oamaru, Norther Otago. As the "head boy," Macintosh showed tremendous academic promise and began to cultivate his passion for the basic sciences. He joined the Royal Flying Corps of the British army at the age of 18 to serve as a fighter pilot in World War I. In 1917, his plane was shot down behind enemy lines in France, and he was held as a prisoner of war in Germany. ${ }^{1,2}$ Fortunately, he escaped and on returning home to the

Address correspondence and reprint requests to Scott W. Cowan, M.D., Associate Professor of Surgery, 1025 Walnut Street, Suite 607 College Building, Philadelphia, PA 19107. E-mail: scott.cowan@ jefferson.edu.
United Kingdom began his medical training at Guys Hospital Medical School. Originally, Macintosh's sole intention was to become a surgeon. However, his interests expanded during his medical training, as he held a part-time position providing anesthesia for dental and surgical clinics. ${ }^{1,2}$

After graduating from medical school in 1924, Macintosh pursued a surgical fellowship at the Royal College of Surgeons of Edinburgh. Realizing the demand for skilled anesthetists, he started what would become a busy and fruitful anesthesia practice in London. ${ }^{3}$ Some officials in the Royal Society of Medicine in London saw his pioneering usage of induction with intravenous barbiturates as suspicious, if fascinating. While Macintosh defended his practice to the Royal Society, the practice's reputation for outstanding patient outcomes and satisfaction became nationally renowned. Sir William Morris, a prominent philanthropist and patient of Macintosh's, attested Macintosh's methods as a viable, "smooth" alternative to the unpleasant nitrous oxide inhalation induction he experienced as a young man. This experience prompted Morris, who had changed his name to Lord Nuffield, to make a generous donation to Oxford University in 1937 to create a postgraduate medical center. ${ }^{3}$ One of his stipulations was that this center should have a Chair of Anesthesia, and that Macintosh should receive the first offer. Macintosh accepted, making him the second professor of anesthesia worldwide. To prepare for the challenges of running a successful academic department, Macintosh traveled to Madison, Wisconsin, to meet his colleague and first such professor of anesthesia, Dr. Ralph Waters. Macintosh would remain the Nuffield Professor of Anesthetics until his retirement in 1965 (Fig. 1).

While he was reluctant at first to leave his stable private practice, it was his foray into academia that inspired his most medically impactful achievements. ${ }^{1-3}$

Macintosh produced a number of textbooks and research papers throughout his career and gave lectures and demonstrations all over the world, even well after his retirement. He lobbied for understaffed hospitals 


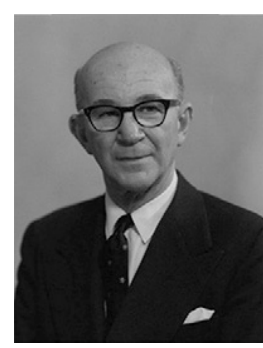

FIG. 1. Portrait of Dr. Robert Reynolds Macintosh, 1961. Photographed by Alexander Bassano of Bassano Ltd. Available from National Portrait Gallery, London, at http://www.npg. org.uk/collections/search/portrait/mw87794/Sir-Robert-ReynoldsMacintosh\#sitter.

to provide anesthesiologists with assistant technicians, a philosophy that has continued to shape the specialty to this day. On this topic, Macintosh once stated that the anesthesia provider "would benefit from the introduction of someone to look after the apparatus, and lend a hand generally in the operating theatres." 3 In 1937, he gave his assistant Richard Salt the first official title of "anesthetic technician." Macintosh himself acknowledged that Salt helped catalyze several of his own scientific advancements, including the Macintosh blade and his ether anesthesia vaporizer. ${ }^{3}$ Above all else, he strongly believed in the values of teamwork and patient safety. The sincerity with which he held these values was apparent vis-à-vis his clinical efforts and technical innovations. He often told colleagues and students, "Most anesthetic accidents are preventable," and preached the importance of making anesthesia "safe and simple." "3 By 1949, he persuaded the Association of Anesthetists to appoint a committee to investigate anesthesia-associated deaths. The idea of this committee was not well taken at first, as it placed all anesthetists in Great Britain under increased pressure and scrutiny. ${ }^{1,2}$ Through this particular endeavor, Macintosh prioritized patient safety above fear of professional retribution in a way that left an indelible mark on the status of anesthesiology for years to come.

In regard to Macintosh's innovations, there are a few that deserve mention. In what is his most widely recognized contribution to medicine, Macintosh would publish an entirely new design for a curved laryngoscope blade in the leading British medical journal, The Lancet, in 1943 (Fig. 2). ${ }^{4,5}$ His laryngoscope was specifically designed for indirect elevation of the epiglottis and exposure of the laryngeal aperture. Macintosh based this design concept on the Boyle-Davis mouth gag device that he frequently used when assisting in tonsillectomies. To make the first prototype, he first asked Salt to attach a Boyle-Davis blade to a laryngoscope handle. After extensive trial and error with a wide range of blade lengths and curvatures, Macintosh crafted a universal adult size blade., 5
July 25, 1944.

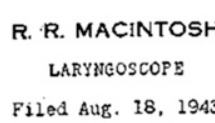

$2,354,471$
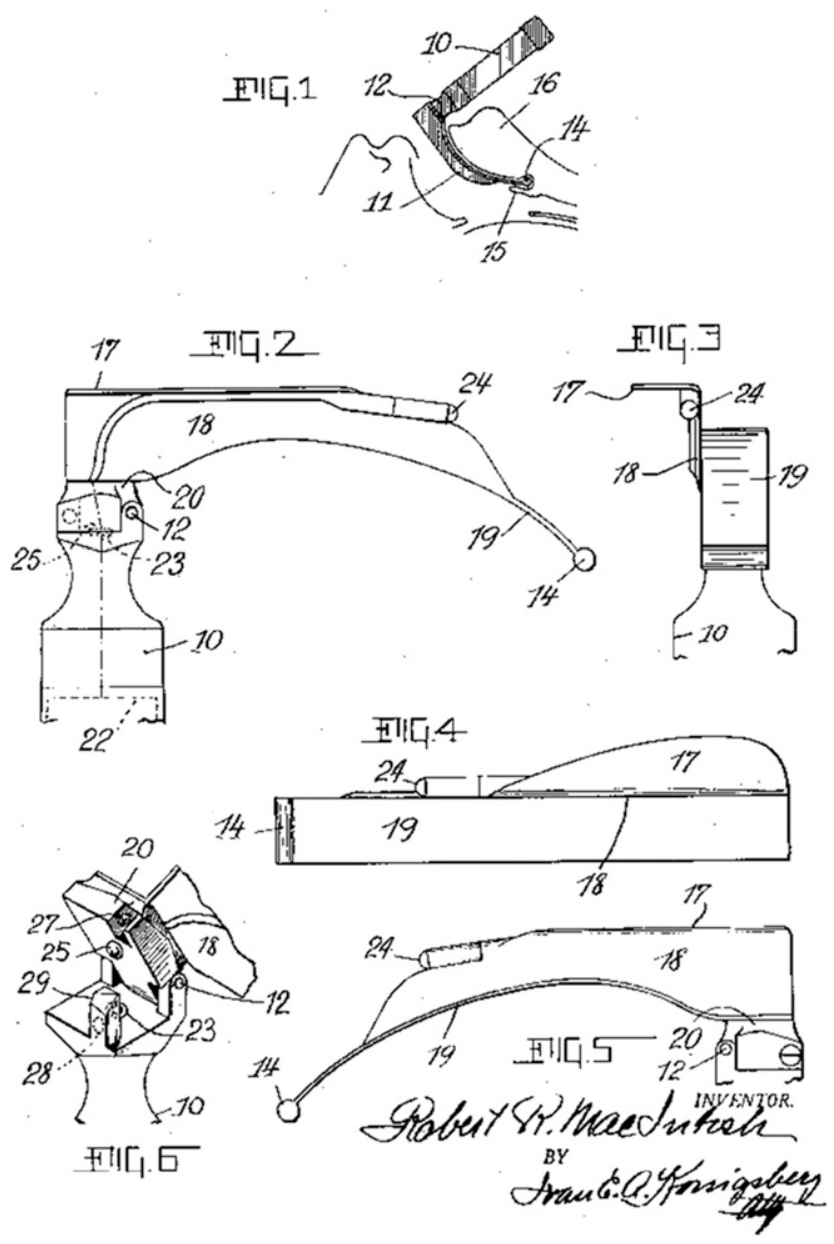

FIG. 2. Original designs for "McIntosh blade" patent, filed by The Foregger Company, Inc. Citation: Macintosh, Robert R. "Laryngoscope." Foregger Company, Inc., assignee. Patent US2354471. July 25, 1944. Available at http://www.google.com/patents/ US2354471.

Several international manufacturing companies began to produce the blade. One company in particular out of New York City applied for a United States patent and, in a curious turn of events, claimed complete proprietary rights to the blade design under the misspelling "McIntosh blade." 4 , 5 Some manufacturers added various adult and pediatric sizes, which Macintosh condemned as anatomically incorrect. ${ }^{4}$ Suffice it to say, Macintosh believed less in marketing and manufacturing than in making airway management safer than ever before.

A few years later, while serving as an anesthesiologist for an American surgeon tending to wounded soldiers in the Spanish Civil War, Macintosh created a portable vaporizer that delivered known concentrations 
of ether anesthesia. True to form, he recognized the help of his Oxford colleague, Dr. H.G. Epstein, by naming the invention the Epstein-Macintosh-Oxford vaporizer.6, 7 Interestingly, it was manufactured in the factory of Morris Cars in Cowley, Oxford, which belonged to William Morris. Around this time, he and Morris also distributed negative pressure ventilators (colloquially referred to as "iron lungs") to polio victims throughout the United Kingdom. ${ }^{6}$ The utility of the EpsteinMacintosh-Oxford vaporizer per se was short lived, as the use of ether anesthesia sharply declined during the early twentieth century. Nevertheless, it advanced the field's understanding of volatile anesthetic delivery and is recognized as a seminal model for modern vaporizers.

Years after his military service, and despite his traumatic experiences therein, Macintosh lent his hand as a physician to serve in World War II. In 1941, he joined the Royal Air Force and held the rank of Air Commodore, treating patients in Royal Air Force hospitals throughout the United Kingdom. ${ }^{1} \mathrm{He}$ redesigned life jackets to prevent the drowning of downed aircraft pilots who landed unconscious in water. These life jackets saved the lives of hundreds of British airmen shot down in the English Channel. ${ }^{2} \mathrm{He}$ also performed experiments with the Royal Air Force Physiological Laboratories, including investigating underwater pressure phenomena and how to survive high-altitude parachute descent. ${ }^{1}$ All of these endeavors led to a myriad of publications and increased awareness of safety in anesthesia. Moreover, they captured the attention and appreciation of Queen Elizabeth, who knighted him in $1955 .^{6}$

Macintosh was beloved by colleagues, students, and patients for his supportive nature, his deft clinical instincts, and his sense of humor. Throughout his life, he showed an admiral ability to balance commitments toward clinical practice, scientific research, military service, and academia. After his retirement, he pursued his passion for travel while maintaining relationships with the department at Oxford. Macintosh's influence on the technical development and worldwide reputation of anesthesiology is unmistakable. In large part, the significant advancements in surgery and anesthesiology in the last several decades can be attributed to Macintosh's lifetime work.

Haig Minassian, B.A. Scott W. Cowan, M.D. Charles J. Yeo, M.D.

Department of Surgery

Thomas Jefferson University

Philadelphia, PA

\section{REFERENCES}

1. Boulton TB. Professor Sir Robert Macintosh, 1897-1989: personal reflections on a remarkable man and his career. Reg Anesth 1993;18:145-54.

2. Sykes K. Careers in Anesthesiology: Three Pioneer British Anaesthetists. Vol. IX. Schaumburg, IL: Wood Library-Museum of Anesthesiology, 2005.

3. Sykes K, Benad G. The influence of Sir Robert Reynolds Macintosh on the development of anaesthesia. Anaesthesiol Reanim 2004;29:91-6.

4. Jephcott A. The Macintosh laryngoscope. Anaesthesia 1984; 39:474-9.

5. Macintosh RR. A new laryngoscope. Lancet 1943;241:205.

6. Croft T. Professor Sir Robert Macintosh, 1897-1989. Resuscitation 2002;54:111-3.

7. Epstein HG, Macintosh RR. An anaesthetic inhaler with automatic thermo-compensation. Anaesthesia 1956;11:83-8. 